\title{
OBITUARY: Arief Budiman (3 January 1941-23 April 2020)
}

Edition 2, 2020

Professor Vedi Hadiz

DOI: 10.37839/MAR2652-550X2.4

For my generation of Indonesian scholars, intellectuals and former activists, the passing of Arief Budiman marks the end of an era.

Buried together with Arief, at least to my mind, once and for all is what was left of the youthful idealism of the rather amorphous, novel and often ramshackle student movement of the 1980s. Not that I feel much nostalgia for the period - that idealism had always been tempered by the realities of general ineffectiveness against the brutal authoritarianism of the New Order in its heyday.

That authoritarianism forced us to vacate our own campuses, due to the harsh clampdown on student organisations in the late 1970s and early 1980s. Our bases of activity were the decrepit surroundings of student hostels and makeshift 'headquarters' where we would congregate away from the roving eyes of the intelligence and security forces, shifting when fearing detection or after receiving uninvited visits.

We were far from the ideal of the heroic youth that periodically finds its way into narratives of Indonesian political history. In fact, every day made us aware of our own social marginality as the New Order behemoth trampled on almost all opposition, while feeding its political and business elites in a frenzy of corruption. It was this marginality that subsequently led some student activists toward labour and peasant organising, thereby distinguishing themselves from predecessors that were more 'gedongan' (literally, living in mansions), having come from relatively elite families. 
But then there was Arief Budiman.

Arief was already a highly respected scholar, public intellectual and political dissident by that time. Hailing from an ethnic Chinese family, which was far from well-off - and therefore doubly marginal - his birth name was Soe Hok Djin. He had a younger brother, Soe Hok Gie, who was semi-legendary amongst activist youths, but died young in a mountain climbing accident in the late 1960s. While students of the University of Indonesia, the brothers were part of the 1966 movement that helped topple Soekarno and install Soeharto's New Order regime, though both quickly fell out with it. Unlike some of their contemporaries, they shunned the state and its appendages, thereby forfeiting likely power and/or wealth. In 1972, Arief departed for Europe and the USA, partly spurred by the fact that he had incurred the personal wrath of Soeharto. The president was particularly irritated when Arief led protests against the Mini Indonesia Project on the outskirts of Jakarta, patronised by Madame Tien Soeharto, and which involved the forced eviction of the local population. Previously, Arief had led a boycott of the first New Order-era general election, which would set the tone for other heavily rigged and orchestrated ones till the fall of the regime in 1998.

The point is that by the time Arief encountered the student movement of the 1980s, he was well and truly ostracised by the New Order establishment that he had helped to usher in. In retrospect, the sense of having in common a certain marginal status in society probably helped to connect the student movement to Arief. I recall that Arief's home in the central Java town of Salatiga was where student activist representatives from Jakarta, Bandung, Yogyakarta and other cities initially met together for the first time in the 1980s. It was a measure of both his generosity and the esteem to which he was held by students that such a meeting took place there.

When I first met Arief, around 1983, he had already set himself up in a small university in Salatiga. Having returned a couple of years earlier to Indonesia with a Harvard PhD in Sociology, one could safely say that this was another of his idiosyncratic life choices. There he helped build a postgraduate programme in 
development studies, which briefly became one of the best in Indonesia. He further developed an international reputation, being instrumental, among other things, in forging a network of Southeast Asian scholars/critics of their respective authoritarian regimes, to which he subsequently introduced me.

From Salatiga, Arief was instrumental in developing a critique of the New Order development path by popularising ideas associated with neo-Marxist analyses of capitalism and dependency theory. This was well received by student activists who were also looking for ways of making sense of the route on which the New Order had taken us.

Here, Arief's skill for distilling complex ideas was in full display in the numerous articles he wrote on the subject, including in mainstream newspapers. This was an incredible feat in itself, given that much effort had to be expended to camouflage the intellectual origins of his ideas because New Order hostility towards Leftist theorising was part of its ideological armoury. But so prodigious was Arief that he also left his mark on debates about gender equality and on literature.

In Australia, Arief may be known primarily from his time as the Foundation Professor of Indonesian Studies at the University of Melbourne, a position from which he retired by 2008. But even his move to Melbourne was due to his inability to countenance abuse of power wherever he saw it. In this case, he was dismissed from Satyawacana University in Salatiga in 1996 because he had protested, with several colleagues, against irregularities in the appointment of a new rector.

In Melbourne, Arief would often feel lonely, I am told, being far away from the hurly burly of Indonesian politics. Still, he contributed significantly to the development of Indonesian Studies at the University of Melbourne, not just through teaching but also regular appearances in the media to comment on Indonesian affairs, especially after 'reformasi'. There is no doubt that Arief greatly helped to revive the national profile of Indonesian Studies in the university.

In writing this, I have resisted the temptation to provide anecdotes on my personal 


\section{MELBOURNE ASIA REVIEW}

interactions with Arief. I will provide only one: After arriving in Melbourne in 2016, I sought out Arief, who I had not seen for some years. Of course, I was aware that his health had deteriorated. I called his wife Leila and made an appointment to see him where he was convalescing in hospital after taking a fall. Leila had warned me that Arief usually did not remember his visitors - this was of course a gentle way to save me from disappointment. But as I walked into his hospital room, Arief raised his head and focussed his gaze directly on me. His words were: 'Vedi, how come you are so fat? You're supposed to be thin!' It occurred to me that, to Arief, I would always be the skinny twenty-something would-be activist and intellectual of decades ago. But I was just pleased to be remembered. My one regret is that there was no time to introduce Arief to today's crop of younger scholars - for whom I am sure he would have been a profound influence and inspiration as well.

This article was co-published with Indonesia at Melbourne.

Listing image: Arief Budiman at a public lecture in the Sidney Myer Asia Building, Melbourne, 2007. Flickr/Cindy Husein.

Banner image credit: Jakarta Post 